\title{
Synthetic routes to degradable copolymers deriving from the biosynthesized polyhydroxyalkanoates: A mini review
}

\author{
Y. Ke $e^{1}$, X. Y. Zhang ${ }^{1}$, S. Ramakrishna ${ }^{2}$, L. M. He ${ }^{1}$, G. Wu ${ }^{3 *}$ \\ ${ }^{1}$ Department of Biomedical Engineering, Key Laboratory of Biomaterials of Guangdong Higher Education Institutes, \\ College of Life Science and Technology, Jinan University, 510632 Guangzhou, China \\ ${ }^{2}$ Guangdong-Hongkong-Macau Institute of CNS Regeneration (GHMICR), Jinan University, 510632 Guangzhou, China \\ ${ }^{3}$ Biomaterial Research Institute, School of Materials Science and Engineering, South China University of Technology, \\ 510641 Guangzhou, China
}

Received 30 May 2015; accepted in revised form 20 August 2015

\begin{abstract}
Polyhydroxyalkanoates are a family of natural polyesters being produced as intracellular carbon and energy reserves by a wide variety of microorganisms. They have developed rapidly in both research and development efforts globally in the last 15 years. Till now, over 100 different types of PHAs have been successfully biosynthesized using both genetic engineering and fermentation techniques. Their unique biodegradable, biocompatible and thermoplastic characteristics make PHAs promising candidates for the commodity and biomedical applications. This review focused on the chemical synthesis of the derivatives of the biosynthesized PHAs.
\end{abstract}

Keywords: polymer synthesis, biopolymers, biodegradable polymers, biocompatible polymers

\section{Introduction}

Hydroxyalkanoates (PHAs) are a family of polyesters that accumulate as carbon/energy or reducingpower storage. Till now, over 100 different types of PHA have been successfully biosynthesized using both genetic engineering and fermentation techniques [1-4]. Their unique biodegradable, biocompatible and thermoplastic characteristics make PHAs promising candidates for commodity applications, including recyclable packing materials, kitchen films, diapers, sanitary napkins. Recently, much interest is focused on the biomedical applications as surgical suture and swabs, wound dressings, vascular graft, blood vessel, and scaffold for new tissue in growth [5-7].

Poly(3-hydroxybutyrate) (P3HB) is the most common short-chain-length PHA, first discovered in 1925 by Lemoigne who described it as a lipid inclu- sion in the bacterium Bacillus megaterium [8]. Several inherent deficiencies of PHB have limited its medical applications, including the brittleness due to the high crystallinity and the narrow thermal processing window because of the thermal instability. PHA copolyesters containing, besides 3-hydroxybutyrate (3HB, Figure 1a), 4-hydroxybutyrate (4HB, Figure 1b) [9-11], 3-hydroxyvalerate (3HV, Figure 1c) [12-16], 4-hydroxyvalerate (4HV, Figure 1d) [17-18], hydroxypropionate (HP, Figure 1e) [1920], hydroxyhexanoate (HHx, Figure 1f) [21-23], and hydroxyoctanoate (HO, Figure 1g) [24] units can be produced by different microorganisms. Varying the copolymer composition affords obtaining copolyesters with adjustable mechanical and processing properties exceeding those of the $\mathrm{P} 3 \mathrm{HB}$ homopolymer. Terpolyesters poly(3-hydroxybutyrate-co-3-hydroxyvalerate-co-4-hydroxybutyrate)

\footnotetext{
${ }^{*}$ Corresponding author, e-mail: imwugang@scut.edu.cn (C) BME-PT
} 


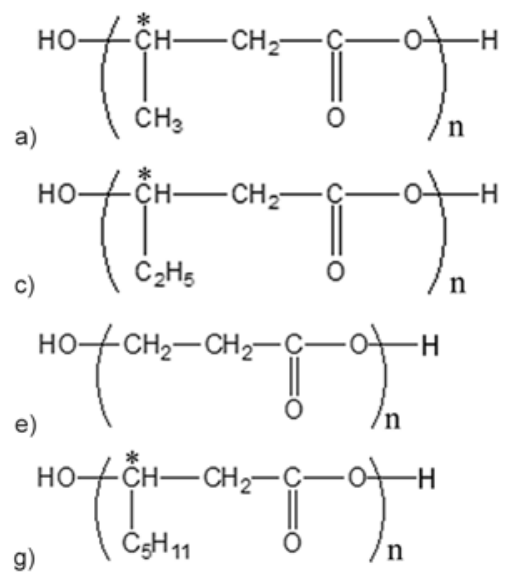<smiles>CCCCCC(=O)O</smiles>

b)

d)<smiles>CC(C)CCC(=O)O</smiles>
f)<smiles>CC(C)CC(=O)O</smiles>

Figure 1. Monomer units of the main PHAs: (a) P3HB; (b) P4HB; (c) P3HV; (d) P4HV; (e) PHP; (f) PHHx; (g) PHO, letter $(n)$ and asterisks $\left(^{*}\right)$ represent the number of repeat units and the chiral centers, respectively

(P3HB3HV4HB) [25-27], poly(3-hydroxybutyrateco-3-hydroxyvalerate-co-3-hydroxyhexanoate) (P3HB3HVHHx) [28, 29] and poly(3-hydroxybutyrate-co-4-hydroxybutyrate-co-3-hydroxyhexanoate) (P3HB4HBHHx) [30, 31] have be synthesized by changing the feedstock and microorganisms.

Natural blocky-structured PHAs have been successfully synthesized in vivo by microorganisms and in vitro. Diblock copolymer PHB- $b$-PHHx was produced by a recombinant Pseudomonas putida KT2442 with its $\beta$-oxidation cycle deleted to its maximum [32]. P3HB- $b$-P3HP was biosynthesized via the engineered Escherichia coli strain from two parallel synthetic pathways that were modulated by independent regulatory systems to produce the $3 \mathrm{HB}$ and 3HP monomers, respectively [33]. PHA synthase from Ralstonia eutropha (PhaCRe) was engineered to acquire an unusual lactate (LA)-polymerizing activity, which incorporated LA units into the P3HB backbone with a block sequence in vivo using recombinant Escherichia coli LS5218 [34]. The mutated PhaC1SG from a thermo-tolerant bacterium (Pseudomonas sp. SG4502) showed high thermal stability in synthesizing P(LA-co-3HB) in an in vitro reaction system by sequential feeding of the corresponding two substrates [35]. Fermentation of Alcaligenes eutrophus in a culture containing polyethylene glycol (PEG) or polysaccharide has produced a hydroxyterminated block copolymer consisting of PHA [36, 37].

Biosynthesis provides a versatile way to produce the copolymers with desired sequence patterns, random or block. However, PHAs still suffer from some disadvantages: the deficiency of the commercialized PHAs, high cost compared to that of petroleum- based polyesters, and the difficulty in controlling the structure and molecular mass, which would be solved to some extent via synthesizing copolymer or functionalizing PHAs chemically. This paper summarized the chemical synthesis of the PHAs derivatives.

\section{PHAs with unsaturated side chains and their derivatives}

The introduction of other functional groups in PHAs has also been achieved via the biosynthesis route. Poly(3-hydroxy undecenoate) (PHU, Figure 2), being obtained from $P$. oleovorans with a mixture of sodium octanoate and 10-undecenoic acid [38], is a novel and multifunctional type of PHA, which has attracted much attention owing to its unsaturated side chains. These vinyl groups can be oxidized to carboxylic acid using osmium tetraoxide/oxone or acidic potassium permanganate treatment $[39,40]$, or converted to alcohol (nearly $100 \%$ hydroxylation) using 9-borobicyclononane [41]. The partially hydroxylated (50 60\%) PHU being treated with potassium permanganate at $20^{\circ} \mathrm{C}$ was completely soluble in polar solvents (80/20 acetone/water, methanol or dimethyl sulfoxide), indicating a considerably enhanced

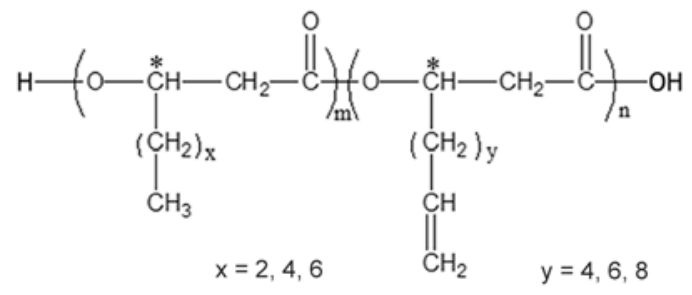

Figure 2. Monomer unit of PHU, letters $(n, m)$ and asterisks $\left(^{*}\right)$ represent the number of repeat units and the chiral centers, respectively 
hydrophilicity [42]. Epoxides-terminated side chains being converted from the vinyl terminal of PHU has been reported to be modified with diethanolamine to obtain a cationic PHA with pendant amine side groups $[43,44]$. When exposed to air at room temperature for 40 days, the unsaturated copolyester formed a highly flexible and biocompatible elastomer [45].

The double bonds of the unsaturated PHAs can be homo-/copolymerized via free radical mechanisms to graft poly(methyl methacrylate) or by UV irradiating to graft PEG in the presence of benzoyl peroxide [46] and benzoyl peroxide [24], respectively. The halogenated PHU could be transformed to macro reversible addition-fragmentation chain transfer agents via the substitution reaction with potassium ethyl xanthate, which further initiated polymerization of $\mathrm{N}$-isopropylacryl amide to obtain thermo-responsive and amphiphilic brush copolymers [47, 48]. Though the side chains of the unsaturated PHAs can be easily grafted to add chemical groups or cross-link with other polymer chains, it has been very difficult to obtain structurally controllable block-PHAs. A $\beta$ oxidation deleted Pseudomonas entomophila was used to biosynthesize block copolymers of 3-hydroxydodecanoate (3HDD) and 3-hydroxy-9-decenoate (3H9D), which was produced by feeding dodecanoic acid firstly to form a P3HDD block followed by adding 9-decenol to form a P3H9D block [49]. This method allows further chemical modification to widen PHA diversity, promising to control the PHA functionality to meet various requirements.

\section{PHAs copolymer via an oligomer-first method}

A two-step reaction is applied in this route: PHAs are first functionalized with termini other than the native hydroxyl and carboxyl groups to produce PHAs oligomers, and these telechelic chains of PHAs have been used for the chain-extension reaction to synthesize new copolymers. PHAs oligomers could be obtained via various thermal or chemical methods with the concomitant partial depolymerization in order to reduce solution viscosities and facilitate subsequent modification.

Pyrolysis is an easy method to produce the functionalized PHA macromonomers. At the moderately low temperature $\left(170 \sim 200^{\circ} \mathrm{C}\right)$, PHB degraded into a well-defined oligomer containing one unsaturated end group, predominantly a trans-alkenyl end group, as well as a carboxylic end group [50]. The dominant thermal degradation occurred via a random chain scission (cis-elimination) with a six-membered ring ester intermediate [51-54]. If 2,2'-bis(2oxazoline) was introduced in the thermal degradation, a hydroxyl-terminated PHBV was achieved with an improved thermal stability [55].

Telechelic oligomers with hydroxyl groups are commonly produced via alcohololysis, a transesterification reaction of alkanediols and high molecularweight PHAs. The chain length of the macrodiols could be easily controlled by the alcoholysis time. When a catalyst (dibutyltin dilaurate) has been applied along with diethylene glycol, a yield of the telechelic hydroxylated PHB (PHB-diol) has been reported to be $80 \%$ [56]. Acid (hydrochloric acid or sulfuric acid) catalyzed the methanolysis to produce PHB and PHBV oligomers, having a free secondary hydroxyl as well as a methyl ester protected carboxylic acid for the two respective chain ends [57, 58]. Špitalský et al. [59] and Akita et al. [60] have studied the alcoholysis of PHB with two types of alcohol (ethylene glycol or glycerol) in the presence of $p$-toluene sulfonic acid, and found that the controlled degradation of PHB proceeded by random chain scission, and the molecular mass decreased by almost two orders of magnitude. The alcoholysis with ethylene glycol was significantly faster than that with glycerol. Different from the thermal degradation, the crystallinity did not change significantly during the alcoholysis.

Abiotic hydrolysis of PHAs is a relatively slow process under mild conditions $[61,62]$. Based on the mechanism of the heterogeneous hydrolysis, the scission of PHB chains occurs at the surfaces and interfaces of lamellar crystals. In acidic or alkaline solutions, PHB can be hydrolyzed via the random scission of the ester bonds, forming insoluble/soluble oligomers or monomeric acids [63]. The unsaturated end group was formed by dehydration of the chain ends by $\beta$-elimination after ester hydrolysis, different from the mechanism of thermal decomposition [64].

Other PHAs oligomers, such as PHB macrodiols with a hydroxyl group and a double bond at different chain ends [65], PHB-amine conjugate containing hydrolysable imine bond [66], chlorination of PHAs (PHB or PHO) and their corresponding quaternary ammonium salts, sodium sulfate salts, and phenyl derivatives [67], have also been produced by 
various chemical methods. These PHAs oligomers could be used for building the block (diblock, triblock, or star block), graft, or even brush type graft copolymers of PHAs via different mechanism, mainly coupling reaction and macroinitiating reaction, to explore the suitable chemical and physical properties, processability and biocompatibility.

\subsection{Coupling reaction}

Coupling reaction is a general and powerful strategy for preparing PHAs derivatives. For example, PHB oligomers were directly coupled with amino groups of chitosan to synthesize graft copolymers $[68,69]$, though the yield was rather low. The indirect coupling reaction usually uses an agent between the PHAs macromonomer and the second component. Acyl chloride, 1,3-N,N-dicyclohexylcarbodiimide (DCC)/4-(dimethylamino) pyridine (DMAP), and diisocyanate are three main coupling agents that have been employed to synthesize PHAs derivatives (Table 1). It should be noted that these impurities (coupling agents) would be left inside the copolymers, so that the coupling reaction is often used for systems without other options.

\subsubsection{Acyl chloride}

Coupling mechanism using acyl chloride as a bridge to link the hydroxyl-terminated PHAs macromonomers with other dihydroxyl-teminated oligomers is a direct method to produce block copolymer. For example, a PHO-diol and a PHB-diol were chosen to produce block copolyesters with terephthaloyl chloride (Figure 3), where a polycondensation reaction occurred between $\mathrm{COCl}$ and $\mathrm{OH}$ groups. Since water can inhibit the polymerization by reacting with $\mathrm{TeCl}$ to give the corresponding acid, the reaction must be carried out under an anhydrous condition and a nitrogen atmosphere [70].

Table 1. Coupling reaction for the synthesis of PHAs derivatives

\begin{tabular}{|c|c|c|c|c|}
\hline Coupling agent & PHAs macromonomers & Other components & Copolymer & References \\
\hline Terephthaloyl chloride & PHB-diol & PHO-diol & Block & [70] \\
\hline \multirow{3}{*}{$\begin{array}{l}\text { 1,3- } N, N \text {-dicyclohexylcarbodiimide } \\
\text { 4-(dimethylamino)pyridine }\end{array}$} & PHB-diol & Methoxy-PEG-monocarboxylic acid & Block & {$[71,72]$} \\
\hline & PHB-diol & $\begin{array}{l}\text { Multifunctional cores (trimethyol propane, } \\
\text { pentaerythiritol or dipentaerthritol), } \\
\varepsilon \text {-caprolactone }\end{array}$ & Star block & [73] \\
\hline & $\begin{array}{l}\text { PHB-COOH } \\
\text { (via thermal degradation) }\end{array}$ & Hydroxyethyl methacrylate & Comb graft & [74] \\
\hline \multirow{10}{*}{ 1,6-hexamethylene diisocyanate } & PHB-diol & PCL-diol & Block & [78] \\
\hline & PHB-diol & PEG & Block & {$[82,85-87]$} \\
\hline & PHB-diol & PCL-PEG-PCL triblock copolydiol & Block & [88] \\
\hline & PHB-diol & Poly(propylene glycol), PEG & Block & {$[92,93]$} \\
\hline & PHB-diol & $\begin{array}{l}\text { Poly(butylene glycol adipate)-diol } O R \\
\text { Poly(diethylene glycol adipate)-diol }\end{array}$ & Block & [79-81] \\
\hline & P3HB4HB-diol & PHBHHx-diol & Block & [75] \\
\hline & \begin{tabular}{|l|} 
P3HB4HB-diol \\
\end{tabular} & PHHxHO-diol & Block & [76] \\
\hline & P3HB4HB-diol & $\begin{array}{l}\text { P3HB4HB-diol with different 4HB contents } \\
\text { and segment lengths }\end{array}$ & Block & [77] \\
\hline & P3HB4HB-diol & PEG & Block & [83] \\
\hline & PHBHHx-diol & PEG & Block & [84] \\
\hline Toluene diisocyanate & PHB-diol & PCL-diol & Block & [94] \\
\hline \multirow{3}{*}{$\begin{array}{l}\text { 2,2,4-Trimethylhexamethylene } \\
\text { diisocyanate }\end{array}$} & PHBV-diol & 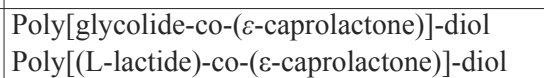 & Block & [95] \\
\hline & PHBV-diol & & Block & [96] \\
\hline & PHB-diol & PCL-diol & Block & [97] \\
\hline \multirow{3}{*}{ L-Lysine methyl ester diisocyanate } & PHB-diol & PHO-diol & Block & [98] \\
\hline & PHBV-diol & & Block & [96] \\
\hline & PHB-diol & PCL-diol & Block & [97] \\
\hline PEG-diisocyanates & P3HB4HB-diol & - & $\begin{array}{l}\text { Alternative } \\
\text { block }\end{array}$ & [99] \\
\hline
\end{tabular}

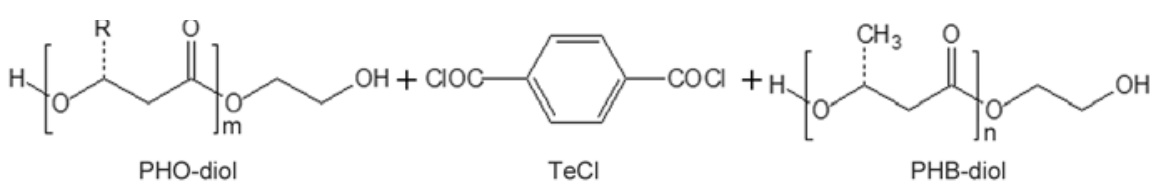

Figure 3. Components for the synthesis of PHO- $b$-PHB copolymer using terephthaloyl chloride as the coupling agent 


\subsubsection{DCC/DMAP}

DCC/DMAP system induces the esterification reaction between PHAs macromonomers and other components. $\mathrm{Li}$ and coworkers $[71,72]$ have synthesized a PEO- $b$-PHB- $b$-PEO triblock copolymers from PHB-diol and methoxy-PEG-monocarboxylic acid by esterification reaction for drug delivery applications. PEO and PHB blocks formed separate crystalline phases in the copolymers: the crystallinity of PHB block increased, while that of the PEO block decreased. The amphiphilic copolymer could selfaggregate into micelles in the aqueous medium, being composed of the hydrophobic PHB core and the hydrophilic PEO corona shell. Once coupled with multifunctional cores (trimethyol propane, pentaerythiritol or dipentaerthritol), the PHB-diol could initiate the ring opening polymerizations of $\varepsilon$ caprolactone (CL) to form star block copolymers with structural variation on arm numbers and lengths [73]. Methacrylic macromonomers of PHB via thermal degradation could copolymerize with hydroxyethyl methacrylate to yield a comb graft, containing $0.5 \sim 14 \mathrm{~mol} \%$ of PHB blocks. However, the graft was controlled poorly with unpredictable molecular mass and broad polydispersity [74].

\subsubsection{Diisocyanate}

1,6-Hexamethylene diisocyanate is a common coupling agent to prepare PHAs elastomers whose segmented and domain structure can be easily controlled by a selection of the monomer units for building the segments, their relative proportions and the length of segments. P3HB4HB has been reported to couple with PHBHHx [75], PHHxHO [76], or only $\mathrm{P} 3 \mathrm{HB} 4 \mathrm{HB}$ with different $4 \mathrm{HB}$ contents and segment lengths [77] based on the dihydroxyl-teminated precursors by melting polymerization. Hydrophobic and biodegradable PCL (soft segment) has been designed to synthesize PCL- $b$-PHB by onestep solution polymerization. The block polymer was semicrystalline, having a PCL crystalline phase along with the PHB crystalline phase and the melting temperature within $126 \sim 148^{\circ} \mathrm{C}$ [78]. Poly (butylenes glycol adipate)-diol (PBA-diol) or poly (diethylene glycol adipate)-diol (PDEGA-diol) as soft segments was also coupled with PHB-diol. When PHB-diol was less than $50 \mathrm{wt} \%$, PBA and PHB phases crystallized separately in PBA- $b$-PHB. However, only PHB segments crystallized in PHB- $b$ PDEGA. Both copolymers showed three-step decom- position, being assigned to the thermal degradation of PHB hard blocks, PBA or PDEGA soft blocks, and the urethane linkage, respectively [79-81]. Hydrophilic PEG could function as the soft segment to synthesize block copolymers, along with PHB [82], P3HB4HB [83], or PHBHHx [84] segment (Figure 4/I). PHB and PEG segments formed separate crystalline phases with a lower crystallinity and a lower melting point than those of their corresponding pre-polymers, and a glass transition temperature between two pre-polymers. Young's modulus and the stress at break of the copolymers increased with increasing PHB segment length or PEG segment length, whereas the strain at break increased with increasing PEG segment length or decreasing PHB segment length $[85,86]$. When fabricated into an electrospun fibrous scaffold, it can be coated with calcium minerals by simple incubation in simulated body fluid, showing a potential application for bone regeneration [87]. The multi-block based on PHB-diol and PCL-PEG-PCL triblock copolydiol by one step solution polymerization was a semicrystalline with two crystallizable PHB and PCLPEG-PCL blocks. The melting temperature of PHB segments was $\sim 40^{\circ} \mathrm{C}$, less than that of neat PHB. Only one glass temperature was exhibited, which corresponded to PCL-PEG-PCL components [88].

Proper choice of the composition of the copolymers (input ratio of hard and soft segments) and the type of macrodiols allows the production of various materials that possess a wide range of thermal and mechanical properties, procesability, hydrophilicity and degradability [89]. It should be noted that small crystalline particles of short-chain PHB (PHB-P, $M_{\mathrm{n}}=$ 2300) released when the block copolymers degraded. Phagocytosis of PHB-P with an irregular shape (1 $10 \mu \mathrm{m})$ at high concentrations $(>10 \mu \mathrm{g} / \mathrm{mL})$ was dose dependent and associated with cell damage in macrophages (J774), but not in mouse fibroblasts (3T3) [90]. Primary rat tibia osteoblasts were capable of phagocytosing PHB-P (diameter of 2 20 $\mu \mathrm{m}$ ), and this process was accompanied at low PHB-P concentrations by dose- and time-dependent alteration of alkaline phospatase activity, but not of collagen type I or osteocalcin [91].

Coupling the second (PEG) and even the third component (polypropyleneglycol, PPG) provided the PHB-based copolymers with an unexpected and unique function. The amphiphilic and thermosensitive triblock underwent a sol-gel-sol transition as 


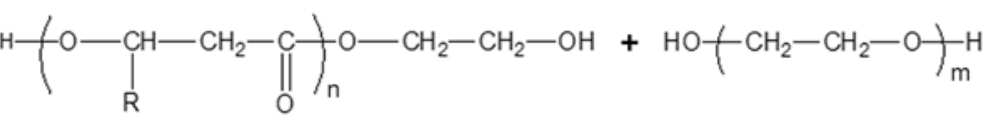

$$
\mathrm{OCN}-\left(\mathrm{CH}_{2}\right)_{6} \mathrm{NCO}
$$
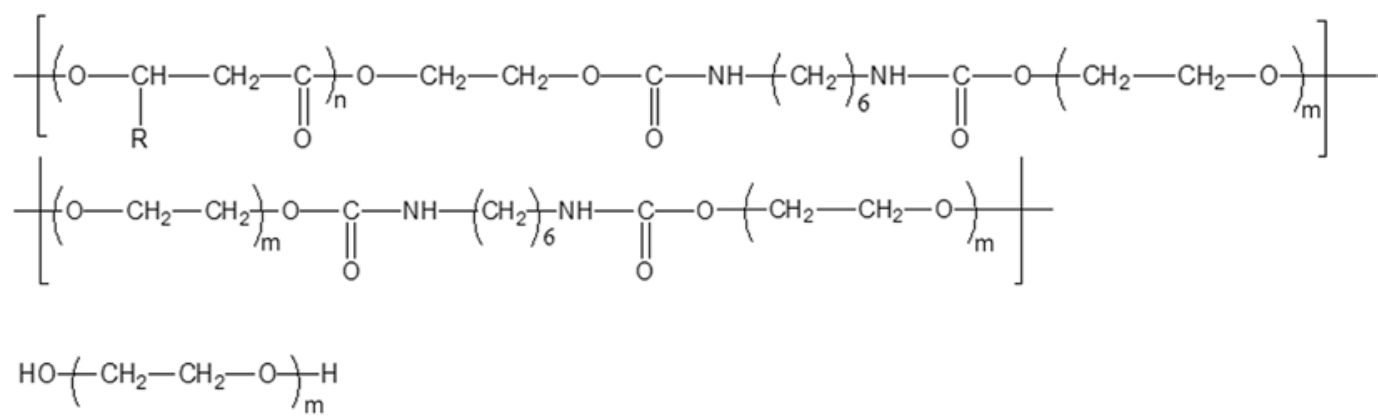

II.

$$
\downarrow \mathrm{OCN}-\mathrm{CH}_{2}+\frac{\mathrm{NCO}}{6}
$$
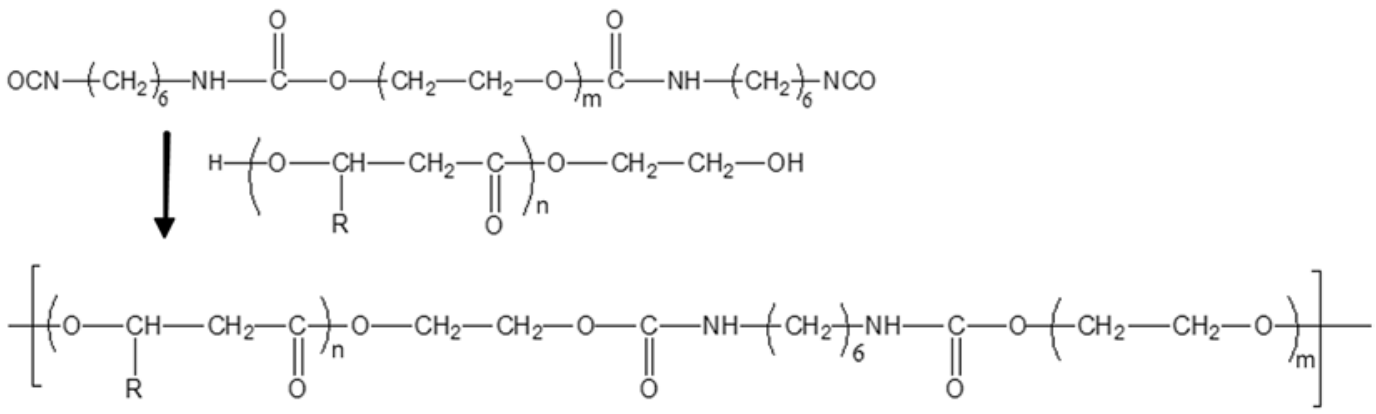

Figure 4. Scheme of the synthesis of the random block copolymer (I) and alternative block copolymer (II) based on PHAsdiol and PEG, $\mathrm{R}=\mathrm{CH}_{3}, \mathrm{C}_{2} \mathrm{H}_{5}, \mathrm{C}_{3} \mathrm{H}_{7}, \mathrm{C}_{5} \mathrm{H}_{11}$

the temperature increased from 4 to $80^{\circ} \mathrm{C}$. It showed a very low critical gelation concentration ranging from 2 to $5 \mathrm{wt} \%$, much lower than that of the commercial thermogelling PEG-PPG-PEG triblock copolymers (15 20 $\mathrm{wt} \%$ or above). Moreover, nonbiodegradable PEG-PPG-PEG triblock copolymers have been reported to show hyperlipidemia and high plasma level of cholesterol in rabbits and rats [92], and less cells (L929 mouse fibroblasts) attachment [93], suggesting that introducing a hydrophilic, biodegradable and biocompatible soft phase in the PHAs block copolymers is an effective way to design novel biomaterials.

Other diisocyanate, including toluene diisocyanate [94], 2,2,4-trimethylhexamethylene diisocyanate [95-97], and L-lysine methyl ester diisocyanate [96-98] have also been applied to synthesize block copolymer. The coupling reaction via diisocyanate must be carried out under anhydrous conditions and an argon or nitrogen atmosphere due to the moisture sensitivity of the coupling agent. More importantly, the above coupling approach lacks the block selectivity and provides the copolymers with the blocks in a random manner, so that the properties of the copolymer were not able to be tuned finely. Pan et al. [99] have attempted to prepare a series of amphiphilic alternative block copolymers based on P3HB4HB-diol and PEG via the terminal coupling reaction of hydroxyl group of P3HB4HB-diol with isocyanate group of PEG-diisocyanates, so that one component can be fully characterized (Figure 4/II). This synthetic methodology provides a way to tailor the exact structure of the biomaterials.

\subsection{Macro-initiating reaction}

Macro-initiators can be used as precursors for the synthesis of block copolymers through radical and ionic polymerization. Arslan et al. [100] have suggested a two-step route to synthesize PHB- $b$-PMMA (where polymethylmethacrylate, PMMA) as follows: A PHB macroinitiator (PHB-MI), having hydroxyl groups at two ends of the polymer chain and an internal azo group, was obtained through the condensation reaction of PHB-diol with 4,4'-azobis(4- 
cyanopentanoyl chloride). Through a redox freeradical polymerization of methyl methacrylate (MMA) with a PHB-MI/Ce(IV) redox system, a multiblock active copolymers with azo groups (PMMA-PHB-MI) were prepared, which was further used in the thermal polymerization of MMA to obtain the final block copolymer. However, it is difficult to produce copolymers with well-controlled molecular mass and low polydispersity in this way.

\subsubsection{Ring opening polymerization}

Ring opening polymerization (ROP) is a useful synthetic route to synthesize biomaterials (Table 2) with various controllable properties for medicinal and pharmaceutical applications [101, 102]. The oligo (3hydroxybutyrate) conjugates with sorbic acid, benzoic acid and $p$-coumaric acid have been obtained via the anionic ring-opening oligomerization of racemic $\beta$-butyrolactone being initiated by sodium sorbate, sodium benzoate, and $p$-coumaric acid potassium salt, respectively [103, 104]. PHAs macroinitiators containing olefinic and carboxylic end groups were obtained by the controlled depolymerization of natural PHAs (PHB, PHBV or PHO), being catalyzed by $\mathrm{KOH} / 18$-crown- 6 complex in a $\mathrm{CHCl}_{3} /$ $\mathrm{H}_{2} \mathrm{O}$ system. These macroinitiators, having similar molecular mass $\left(M_{\mathrm{n}}=3000\right)$ and a unimodal molecular mass distribution, were then used in anionic ROP of $\beta$-butyrolactone to obtain the respective diblock copolymers of natural origin PHA and aPHB [105-107].
Macroinitiators of PHAs, $\mathrm{PHB}-\mathrm{O}-\mathrm{AlEt}_{2}$ being produced from PHB-diol and $\mathrm{AlEt}_{3}$, can initiate ROP of other monomers ( $\varepsilon$-caprolactone and lactic acid) to produce PHB-PCL, PHB-D,L-PLA, and PHB-LPLA diblock copolymers, respectively. These diblock copolymers may serve as emulsifiers for the respective blends of the homopolymers [58]. However, it is well accepted that aluminum ethyl cannot be used to synthesize degradable biomaterials due to the retention of aluminum in vivo and low catalytic efficiency.

Alkyl tin carboxylate is the most common catalyst for the synthesis of PLA and PCL because of the high catalytic activity. The triblock copolymers containing PHBV and PCL units were synthesized by using PHBV2000 as a macroinitiator to carry out ROP of $\varepsilon$-caprolactone in the presence of dibutyltin dilaurate at $130^{\circ} \mathrm{C}$. It was found that the crystallization rate of PCL block increased gradually with the increase of PCL content, though both blocks crystallized more difficultly than the corresponding homopolymers [108]. Methyl-PHB oligomers containing hydroxyl and carboxyl end groups have been reported to initiate a controlled coordination insertion ROP of D,L-lactide and $\varepsilon$-caprolactone via the catalyst of stannous 2-ethylhexanoate, respectively (Figure 5). The triblock copolymers PHB-PLA-PCL showed potential applications as drug release carriers, or surface coatings on other biomedical devices [109]. It should be noted that the toxic nature of stannous ethylhexanoate is a big obstacle for its use

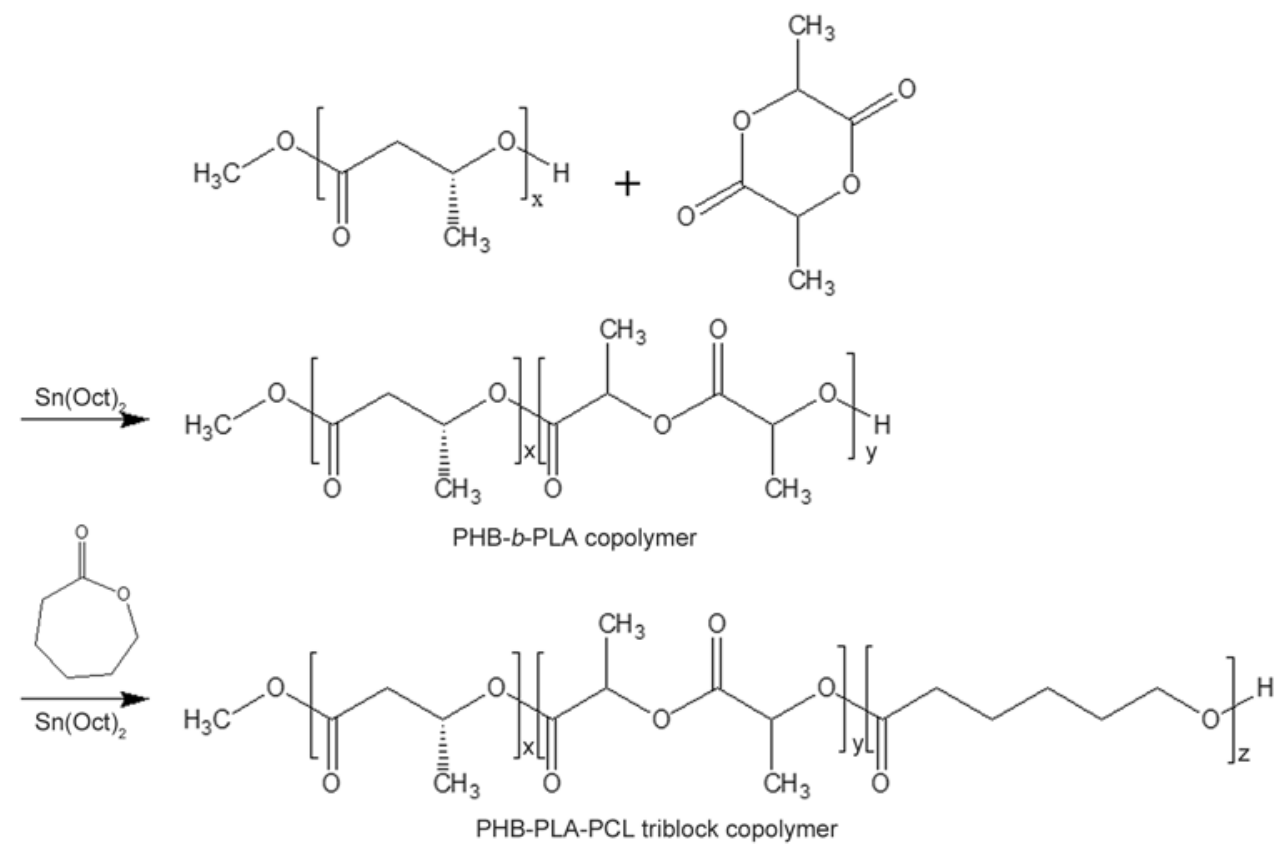

Figure 5. Scheme of the two-step synthesis of the PHB-PLA-PCL triblock copolymer through ring opening polymerization 
Ke et al. - eXPRESS Polymer Letters Vol.10, No.1 (2016) 36-53

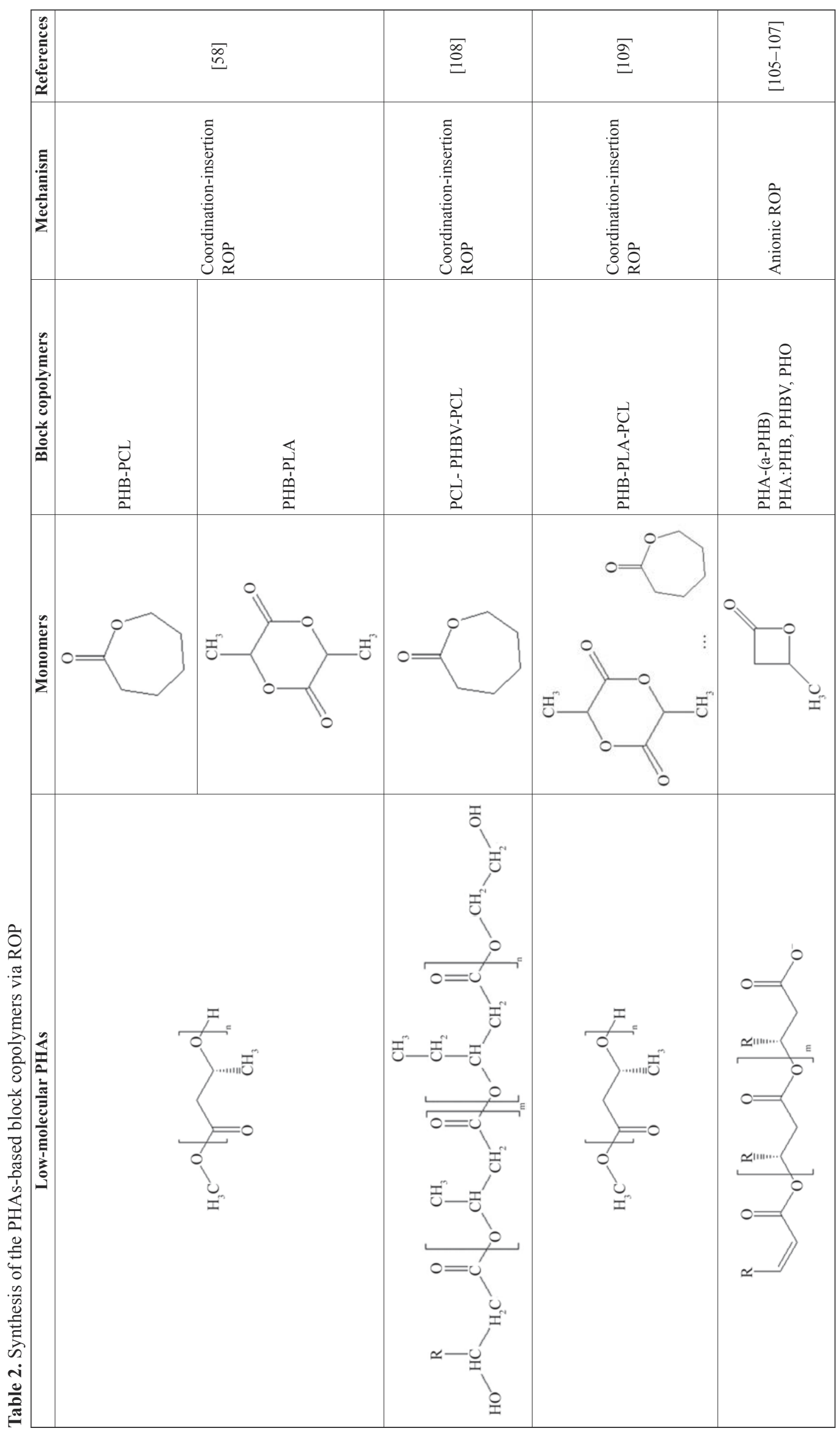


in biomedical application, though it has been granted as a food additive by FDA. Another problem is the rather low rate of ROP. Therefore, catalysts or cocatalysts that enable the rate of polymerization and/or the applicability of the reactions to commercially viable systems to be increased would be the focus of ROP in the next few years.

\subsubsection{Atom transfer radical polymerization}

Atom transfer radical polymerization (ATRP) has been attracting much attention as a new route to synthesizing well-defined polymers $[110,111]$. Halogenated PHAs as macroinitiators can be used in ATRP of vinyl monomers to obtain the block, graft, or brush type multi-graft copolymers. The starting dibromo-terminated PHB (Br-PHB-Br) macroinitiator (Figure 6/II) was usually obtained by the reaction of the terminal hydroxyl of PHB-diol (Figure 6/I) with 2-bromoisobutyryl bromide. The macroinitiator then initiated $N$-isopropylacrylamide in dioxane to form the triblock copolymer with PHB as the central hydrophobic block and PNIPAAm as the flanking block segment (Figure 6/III, 6a). The exciting potential for PNIPAAm-PHB-PNIPAAm lied in its low critical micelle concentrations, the tunability of the biodegradability and the loading capacities by variation in its composition. The water-soluble copolymers formed core-corona-type micelle aggregates with the critical micelle concentrations of $(1.5 \sim 41.1) \mathrm{mg} / \mathrm{L}$ and the partition coefficients of $(1.64 \sim 20.42) \cdot 10^{5}$. The length of PNIPAAm blocks on either side of the PHB block could be restricted to a molecular mass of $<20000 \mathrm{~g} / \mathrm{mol}$ so as to allow the final degraded fragment to be easily excreted from the body via renal filtration. Moreover, the hydrophobicity of the micellar core could be controlled by adjusting the composition of the copolymer to tune the encapsulation efficiency of hydrophobic drugs [112].

The dibromo-terminated PHB macroinitiator induced the polymerization of 2-(dimethylamino)ethyl methacrylate (DMAEMA, Figure 6/III, 6b) and poly (tertbutyl acrylate) (Figure 6/III, 6c) either. The former amphiphilic PDMAEMA-PHB-PDMAEMA triblock copolymer showed lower toxicity and better gene transfection efficiency than polyethyleneimine or PDMAEMA homopolymers [113]. The latter presented a microphase-separated structure at higher<smiles>[R]C(O)CC(=O)OCCO</smiles>

II.<smiles>[R]C(CC(=O)OCCOC(=O)C(C)(C)Br)OC(=O)C(C)(C)Br</smiles><smiles>[R]C(CC(=O)OCCOC(=O)C(C)(C)C([R])(C)Br)OC(=O)C(C)(C)C(=O)OCCOC(=O)C([R])(C)Br</smiles>

III.<smiles>[R]C(CC)C(=O)NC(C)C</smiles>

a)

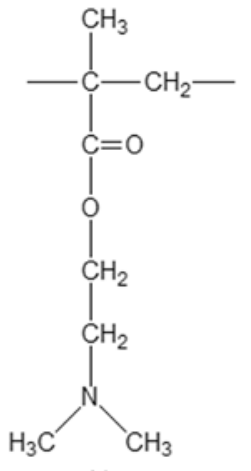

b)<smiles>CCC(C)C(=O)OC(C)(C)C</smiles>

c)

Figure 6. Synthesis of PHB based triblock copolymer by ATRP. I. PHB-diol; II. Br-PHB-Br; III. R'-PHB-R' triblock copolymer: (a) poly( $N$-isopropylacrylamide); (b) poly(2-(dimethylamino)ethyl methacrylate); (c) poly(tertbutyl acrylate), $\mathrm{R}=\mathrm{CH}_{3}, \mathrm{C}_{2} \mathrm{H}_{5}, \mathrm{C}_{3} \mathrm{H}_{7}, \mathrm{C}_{5} \mathrm{H}_{11}$ 
PHB block content, along with better thermal stability than their respective homopolymers [114].

Graft copolymers based on PHB macromonomers can be synthesized in a one-step procedure via ATRP [115]. Vinyl monomers, methyl methacrylate (MMA) or styrene (S), have been initiated by PHA-Cl (macroinitiator) using cuprous chloride $(\mathrm{CuCl}) / 2,2^{\prime}$-bipyridine complex (catalyst) to obtain PHA-g-PMMA or PHA-g-PS brush type graft copolymers with different numbers of side arms. Further, the multigraft brush copolymers PHO-g-PMMA (with more PMMA content) and PHO-g-(PMMA- $b$-PS) were synthesized via ATRP of MMA and S using PHO- $g$ PMMA-Cl as macroinitiator [116, 117]. A brush copolymer composed of the PHB chain and PEG brushes was designed as amphiphilic self-aggregating species with potential application in the healthcare field [118].

The graft copolymers via ATRP were of lower polydispersity $(\sim 1.2)$ than the ones by the conventional free radical polymerization (FRP, 1.6 2.1), and lower molecular mass ( 20 000 for ATRP, 31800 84100 for FRP) [119]. Usually, ATRP is characterized by the well-controlled molecular mass and polydispersity of a polymer, which depends on fast initiation with respect to propagation at a low radical concentration and a fast dynamic equilibrium between the active and dormant radicals. Therefore, the rate of polymerization is rather slow, and the solvent polarity could significantly affect the equilibrium of the active and dormant species. The reaction should be performed under a nitrogen atmosphere and anhydrous conditions, because $\mathrm{O}_{2}$ and water could be a hindrance to the polymerization. Another key prob- lem is the ageing of macromolecules by the remaining transition metal complex.

\section{Direct route to synthesizing PHAs derivatives}

Theoratically, the simplest method to synthesize PHAs derivatives is to link the second component and PHAs directly through a coupling agent (Table 3), for example, PHB-co-PEG copolymer by toluene diisocyanate (coupling agent). Unexpectedly, the main product was the homopolymer PEG other than the copolymer owing to the limited hydroxyl on the macromolecular chains [120]. Active polymers containing peroxide groups 'in chain' have been reported as coupling agents to be grafted onto poly(hydroxyl nonanoate) at $80^{\circ} \mathrm{C}$. But polystyrene or poly(methyl methacrylate) need to be treated first by using oligo(adipoyl-2,5-dimethylhexane-2,5-diyl peroxide) or oligo(dodecanedioyl peroxide) to obtain the active polymers [121-123].

Catalyzed transesterification is a green chemical method, accompanied with the pyrolysis of PHAs melt of high molecular mass. Increasing reaction temperature and/or reaction time are advantageous to the reaction. Through a transesterification reaction in the presence of 4-toluenesulfonic acid monohydrate, oligo(3HB-co-4HB) conjugate with (4-chloro2-methylphenoxy)acetic acid was synthesized in one pot under an argon atmosphere. This conjugate could be used as biodegradable controlled-release systems of pesticides with potentially higher resistance to weather conditions in comparison to conventional forms of pesticides [124]. If a nucleophile (monomethoxy PEG, mPEG) empolyed in the trans-

Table 3. Direct route to synthesizing PHAs derivatives

\begin{tabular}{|l|l|l|l|l|}
\hline \multicolumn{1}{|c|}{ Second monomer/polymer } & \multicolumn{1}{|c|}{ PHAs } & Copolymer & \multicolumn{1}{|c|}{ Initiator/catalyst } & \multicolumn{1}{c|}{ Synthetic route } \\
\hline Acrylic acid & $\begin{array}{l}\text { PHB } \\
\text { PHBV }\end{array}$ & Graft & $\gamma$ radiation & Free radical polymerization \\
\hline Isoprene & PHB & Graft & $\gamma$ radiation & Free radical polymerization \\
\hline \multirow{2}{*}{ Maleic anhydride } & PHB & Graft & Benzoyl peroxide & Free radical polymerization \\
\cline { 2 - 6 } & Graft & $\gamma$ radiation & Free radical polymerization \\
\hline $\begin{array}{l}\text { Phenyl vinyl ketone } \\
\text { 2-Hydroxyethyl methacrylate }\end{array}$ & PHBPHBV & Graft & $\gamma$ radiation & Free radical polymerization \\
\hline Methyl methacrylate & PHU & Graft & Benzoyl peroxide & Free radical polymerization \\
\hline $\begin{array}{l}\text { Monoacrylate PEG } \\
\text { Monomethoxy PEG }\end{array}$ & PHU & Graft & Benzoyl peroxide & Free radical polymerization \\
\hline$N$-isopropyl acryl amide & PHB & Diblock & Bis(2-ethylhexanoate) tin & Transesterification \\
\hline PCL & PHU-Br & Graft & & $\begin{array}{l}\text { Reversible addition-fragmentation } \\
\text { chain transfer }\end{array}$ \\
\hline Styrene & PHB & Diblock & Stannous octoate & Transesterification \\
\hline
\end{tabular}




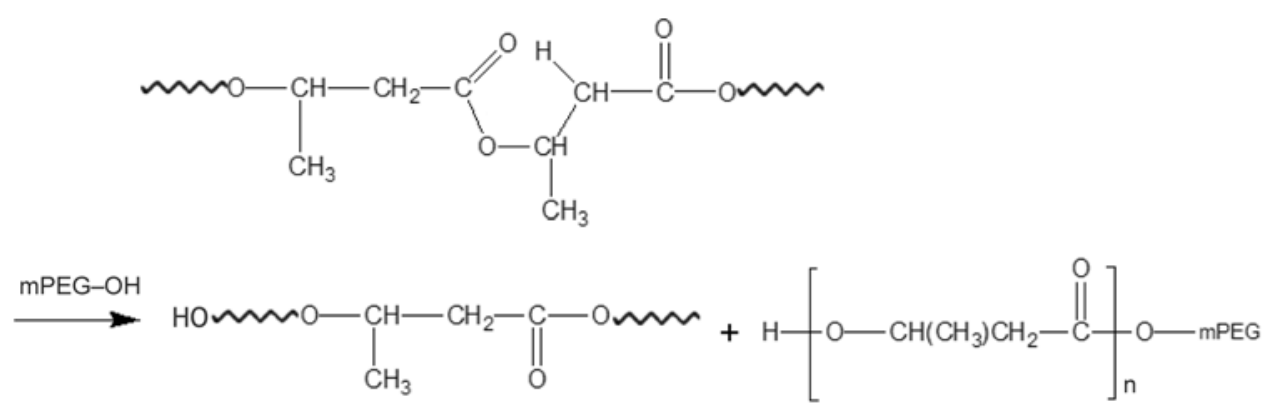

Figure 7. Scheme of the catalyzed transesterification reaction between PHB and mPEG

esterification under bis(2-ethylhexanoate) tin (catalyst), a PHB- $b$-mPEG copolymer was formed (Figure 7). The diblock copolymers were amphiphilic and could be self-assembled into sterically stabilized colloidal suspensions of PHB crystalline lamellae. This process was faster than the condensation reactions between $\mathrm{mPEG}$ and PHB oligomers, so that it is difficult to control the molecular mass of the PHB moiety. The yield was much higher and the contamination of products by the reagents like DCC and DMAP was avoided [125]. The transesterification of thermally unstable copolymer PHB- $b$-PCL could be conducted in liquid phase using stannous octoate as a catalyzer. The crystallization behavior of PHB- $b$-PCL copolyesters altered evidently with the increase in PCL content, though the crystalline structure of PHB remained unchanged [126].

Grafting polymerization using benzoyl peroxide as an initiator was often applied to introduce second component onto the PHAs chains, such as grafting polymerization of phenyl vinyl ketone onto PHBV under nitrogen atmosphere [127]. However, long graft chains may cause new environmental problems. Maleic anhydride showed good reactivity and controllability in free-radical polymerization so as to avoid long and undegradable graft chains via homopolymerization. The crystallization temperature of the graft decreased, and the thermal decomposition temperature increased by $\sim 20^{\circ} \mathrm{C}$ compared with that of PHB homopolymer [128-131]. The drawback of the benzoyl peroxide-initiated grafting polymerization lies in the high reaction temperature, the large amount of solvents and high energy consumption, and the difficulties in purifying the product. The $\gamma$-radiation grafting polymerization could be done at the ambient temperature without any initiator. Vinyl monomers, such as methyl methacrylate or 2-hydroxyethyl methacrylate [132, 133], styrene [134, 135], isoprene [136], acrylic acid [137], and maleic anhydride [138] have been reported to be grafted onto PHB or PHBV with a high yield (up to $80 \%$ ).

\section{Conclusions}

New commercialized PHAs via biosynthesis route would burst with the development of research and industrial technique in the next few years, though time- and money-consuming procedures to bio-synthesize PHAs with specific functional groups are needed. The derivatives based on these novel PHAs will increase to meet the requirement for the final applications. The direct route to synthesizing the PHAs derivatives is limited owing to the low yield and purity, while the two-step route is advantageous to developing the structure- and property-controlled PHAs derivatives, especially when the living polymerization is applied in the second step. The challenge involves preparing the PHAs' oligomers with low polydispersity index.

The new macromolecular synthesis reaction and mechanism stimulates us to develop the block (diblock, triblock, or star block), graft, or even brush type graft copolymers of PHAs into promising candidates as biomaterials. The biocompatibility is still the most essential properties of the PHAs derivatives for the biomedical application. Therefore, the research relevant to the biocompatible components and initiator/stimulators will be an important key to developing the PHAs derivatives.

\section{Acknowledgements}

This study was financially supported by the National Natural Science Foundation of China (31470934, 51572110), the Leading Talents of Guangdong Province (87014002), Pearl River Nova Program of Guangzhou (2014J2200001), and Guangdong Natural Science Foundation (9451063201003024) of China. 


\section{References}

[1] Poirier Y., Somerville C., Schechtman L. A., Satkowski M. M., Noda I.: Synthesis of high-molecular-weight poly([r]-(-)-3-hydroxybutyrate) in transgenic Arabidopsis thaliana plant cells. International Journal of Biological Macromolecules, 17, 7-12 (1995). DOI: 10.1016/0141-8130(95)93511-U

[2] Steinbüchel A., Valentin H. E., Schönebaum A. J.: Application of recombinant gene technology for production of polyhydroxyalkanoic acids: Biosynthesis of poly(4hydroxybutyric acid) homopolyester. Journal of Environmental Polymer Degradation, 2, 67-74 (1994). DOI: $10.1007 / \mathrm{BF} 02074775$

[3] Anderson A. J., Dawes E. A.: Occurrence metabolism metabolic role and industrial uses of bacterial polyhydroxyalkanoates. Microbiological Reviews, 54, 450472 (1991).

[4] Batcha A. F. M., Prasad D. M. R., Khan M. R., Abdullah H.: Biosynthesis of poly(3-hydroxybutyrate) (PHB) by Cupriavidus necator $\mathrm{H} 16$ from jatropha oil as carbon source. Bioprocess and Biosystems Engineering, 37, 943-951 (2014). DOI: $10.1007 / \mathrm{s} 00449-013-1066-4$

[5] Holmes P. A.: Applications of PHB - A microbially produced biodegradable thermoplastic. Physics in Technology, 16, 32-36 (1985).

DOI: $10.1088 / 0305-4624 / 16 / 1 / 305$

[6] Lee S. Y.: Plastic bacteria? Progress and prospects for polyhydroxyalkanoate production in bacteria. Trends in Biotechnology, 14, 431-438 (1996). DOI: 10.1016/0167-7799(96)10061-5

[7] Bugnicourt E., Cinelli P., Lazzeri A., Alvarez V.: Polyhydroxyalkanoate (PHA): Review of synthesis characteristics processing and potential applications in packaging. Express Polymer Letters, 8, 791-808 (2014). DOI: $10.3144 /$ expresspolymlett.2014.82

[8] Lemoigne M.: Products of dehydration and polymerisation of hydroxybutyric acid (in French). Bulletin de la Société de Chimie Biologique, 8, 770-782 (1926).

[9] Meszynska A., Pollet E., Odelius K., Hakkarainen M., Avérous L.: Effect of oligo-hydroxyalkanoates on poly (3-hydroxybutyrate-co-4-hydroxybutyrate)-based systems. Macromolecular Materials and Engineering, 300, 661-666 (2015).

DOI: $10.1002 /$ mame.201500026

[10] An J., Wang K., Chen S., Kong M., Teng Y., Wang L., Song C., Kong D., Wang S.: Biodegradability, cellular compatibility and cell infiltration of poly(3-hydroxybutyrate-co-4-hydroxybutyrate) in comparison with poly(e-caprolactone) and poly(lactide-co-glycolide). Journal of Bioactive and Compatible Polymers, 30, 209-221 (2015).

DOI: $10.1177 / 0883911515569006$

[11] Sridhar V., Lee I., Chun H. H., Park H.: Graphene reinforced biodegradable poly(3-hydroxybutyrate-co-4hydroxybutyrate) nano-composites. Express Polymer Letters, 7, 320-328 (2013). DOI: $10.3144 /$ expresspolymlett.2013.29
[12] Doi Y., Kunnioka M., Nakamura Y., Soga K.: Biosynthesis of copolyesters in Alcaligenes eutrophus H16 from carbon-13 labeled acetate and propionate. Macromolecules, 20, 2988-2991 (1987).

DOI: $10.1021 / \mathrm{ma} 00178 \mathrm{a} 006$

[13] Kamiya N., Yamamoto Y., Inoue Y., Chujo R., Doi Y.: Microstructure of bacterially synthesized poly(3hydroxybutyrate-co-3-hydroxyvalerate). Macromolecules, 22, 1676-1682 (1989).

DOI: $10.1021 / \mathrm{ma} 00194 \mathrm{a} 030$

[14] Mitomo H., Morishita N., Doi Y.: Composition range of crystal phase transition of isodimorphism in poly(3hydroxybutyrate-co-3-hydroxyvalerate). Macromolecules, 26, 5809-5811 (1993).

DOI: $10.1021 / \mathrm{ma} 00073 \mathrm{a} 041$

[15] García I. L., López J. A., Dorado M. P., Kopsahelis N., Alexandri M., Papanikolaou S., Villar M. A., Koutinas A. A.: Evaluation of by-products from the biodiesel industry as fermentation feedstock for poly(3-hydroxybutyrate-co-3-hydroxyvalerate) production by Cupriavidus necator. Bioresource Technology, 130, 16-22 (2013).

DOI: 10.1016/j.biortech.2012.11.088

[16] Phukon P., Saikia J. P., Konwar B. K.: Bio-plastic (P3HB-co-3HV) from Bacillus circulans (MTCC 8167) and its biodegradation. Colloids and Surfaces B: Biointerfaces 92, 30-34 (2012).

DOI: 10.1016/j.colsurfb.2011.11.011

[17] Doi Y., Segawa M., Kunika M.: Biosynthesis and characterization of poly(3-hydroxybutyrate-co-4-hydroxybutyrate) in Alcaligenes eutrophus. International Journal of Biological Macromolecules, 12, 106-111 (1990). DOI: 10.1016/0141-8130(90)90061-E

[18] Shi F., Ashby R. D., Gross R. A.: Fractionation and characterization of microbial polyesters containing 3hydroxybutyrate and 4-hydroxybutyrate repeat units. Macromolecules, 30, 2521-2523 (1997).

DOI: $10.1021 / \mathrm{ma9} 617375$

[19] Hiramitsu M., Doi Y.: Microbial synthesis and characterization of poly(3-hydroxybutyrate-co-3-hydroxypropionate). Polymer, 34, 4782-4786 (1993). DOI: 10.1016/0032-3861(93)90719-Q

[20] Shimamura E., Scandora M., Doi Y.: Microbial synthesis and characterization of poly(3-hydroxybutyrate-co3-hydroxypropionate). Macromolecules, 27, 44294435 (1994). DOI: $10.1021 / \mathrm{ma} 00094 \mathrm{a} 003$

[21] Shimamura E., Kasuya K., Kobayashi G., Shiotani T., Shima Y., Doi Y.: Physical properties and biodegradability of microbial poly(3-hydroxybutyrate-co-3-hydroxyhexanoate). Macromolecules, 27, 878-880 (1994). DOI: 10.1021/ma00081a041

[22] Doi Y., Kitamura S., Abe H.: Microbial synthesis and characterization of poly(3-hydroxybutyrate-co-3hydroxyhexanoate). Macromolecules, 28, 4822-4828 (1995). DOI: $10.1021 / \mathrm{ma} 00118 \mathrm{a} 007$ 
[23] Lee S. H., Oh D. H., Ahn W. S., Lee Y., Choi J-I., Lee S. Y.: Production of poly(3-hydroxubutyrate-co-3-hydroxyhexanoate) by high-cell-density cultivation of Aeromonas hydrophila. Biotechnology and Bioengineering, 67, 240-244 (2000).

DOI: 10.1002/(SICI)1097-0290(20000120)67:2<240:: AID-BIT14>3.0.CO;2-F

[24] Lee J., McCarthy S.: Biodegradable poly(lactic acid) blends with chemically modified polyhydroxyoctanoate through chain extension. Journal of Polymers and the Environment, 17, 240-247 (2009).

DOI: 10.1007/s10924-009-0144-9

[25] Madden L. A., Anderson A. J., Asrar J., Berger P., Garrett P.: Production and characterization of poly(3hydroxybutyrate-co-3-hydroxyvalerate-co-4-hydroxybutyrate) synthesized by Ralstonia eutropha in fedbatch cultures. Polymer, 41, 3499-3505 (2000).

DOI: 10.1016/S0032-3861(99)00611-4

[26] Chanptateep S., Kulpreecha S.: Production and characterization of biodegradable terpolymer poly(3-hydroxybutyrate-co-3-hydroxyvalerate-co-4-hydroxybutyrate) by Alcaligenes sp. A-04. Journal of Bioscience and Bioengineering, 101, 51-56 (2006).

DOI: $10.1263 / \mathrm{jbb} .101 .51$

[27] Hermann-Krauss C., Koller M., Muhr A., Fasl H., Stelzer F., Braunegg G.: Archaeal production of polyhydroxyalkanoate (PHA) co- and terpolyesters from biodiesel industry-derived by-products. Archaea, 2013, 129268/1-129268/10 (2013).

DOI: $10.1155 / 2013 / 129268$

[28] Park S. J., Ahn W. S., Green P. R., Lee S. Y.: Biosynthesis of poly(3-hydroxybutyrate-co-3-hydroxyvalerate-co-3-hydroxyhexanoate) by metabolically engineered Escherichia coli strains. Biotechnology and Bioengineering, 74, 81-86 (2001).

[29] Zhao W., Chen G-Q.: Production and characterization of terpolyester poly(3-hydroxybutyrate-co-3-hydroxyvalerate-co-3-hydroxyhexanoate) by recombinant Aeromonas hydrophila 4AK4 harboring genes phaAB. Process Biochemistry, 42, 1342-1347 (2007). DOI: $10.1016 /$ j.procbio.2007.07.006

[30] Xie W. P., Chen G-Q.: Production and characterization of terpolyester poly(3-hydroxybutyrate-co-4-hydroxybutyrate-co-3-hydroxyhexanoate) by recombinant Aeromonas hydrophila 4AK4 harboring genes phaPCJ. Biochemical Engineering Journal, 38, 384-389 (2008). DOI: $10.1016 /$ j.bej.2007.08.002

[31] Liu Q., Chen G-Q.: In vitro biocompatibility and degradation of terpolyester 3HB-co-4HB-co-3HHx, consisting of 3-hydroxybutyrate, 4-hydroxybutyrate and 3hydroxyhexanoate. Journal of Biomaterials Science, Polymer Edition, 19, 1521-1533 (2008).

DOI: $\underline{10.1163 / 156856208786140391}$
[32] Tripathi L., Wu L-P., Chen J., Chen G-Q.: Synthesis of diblock copolymer poly-3-hydroxybutyrate-block-poly3-hydroxyhexanoate [PHB- $b$-PHHx] by a $\beta$-oxidation weakened Pseudomonas putida KT2442. Microbial Cell Factories, 11, 44/1-44/11 (2012).

DOI: $10.1186 / 1475-2859-11-44$

[33] Wang Q., Yang P., Xian M., Liu H., Cao Y., Yang Y., Zhao G.: Production of block copolymer poly(3-hydroxybutyrate)-block-poly(3-hydroxypropionate) with adjustable structure from an inexpensive carbon source. ACS Macro Letters, 2, 996-1000 (2013). DOI: $10.1021 / \mathrm{mz} 400446 \mathrm{~g}$

[34] Ochi A., Matsumoto K., Ooba T., Sakai K., Tsuge T., Taguchi S.: Engineering of class I lactate-polymerizing polyhydroxyalkanoate synthases from Ralstonia eutropha that synthesize lactate-based polyester with a block nature. Applied Microbiology and Biotechnology, 97, 3441-3447 (2013).

DOI: $10.1007 / \mathrm{s} 00253-012-4231-9$

[35] Tajima K., Han X., Satoh Y., Ishii A., Araki Y., Munekata M., Taguchi S.: In vitro synthesis of polyhydroxyalkanoate (PHA) incorporating lactate (LA) with a block sequence by using a newly engineered thermostable PHA synthase from Pseudomonas sp. SG4502 with acquired LA-polymerizing activity. Applied Microbiology and Biotechnology, 94, 365-376 (2012).

DOI: $10.1007 / \mathrm{s} 00253-011-3840-\mathrm{Z}$

[36] Shi F. Y., Gross R. A., Rutherford D. R.: Microbial polyester synthesis: Effects of poly(ethylene glycol) on product composition, repeat unit sequence, and end group structure. Macromolecules, 29, 10-17 (1996).

DOI: $10.1021 / \mathrm{ma} 950707 \mathrm{j}$

[37] Shi F., Ashby R., Gross R. A.: Use of poly(ethylene glycol)s to regulate poly(3-hydroxybutyrate) molecular weight during Alcaligenes eutrophus cultivations. Macromolecules, 29, 7753-7758 (1996).

DOI: $10.1021 / \mathrm{ma} 960805 \mathrm{k}$

[38] Park W. H., Lenz R. W., Goodwin S.: Epoxidation of bacterial polyesters with unsaturated side chains. I. Production and epoxidation of polyesters from 10-undecenoic acid. Macromolecules, 31, 1480-1486 (1998). DOI: $10.1021 / \mathrm{ma9714528}$

[39] Stigers D. J., Tew G. N.: Poly(3-hydroxyalkanoate)s functionalized with carboxylic acid groups in the side chain. Biomacromolecules, 4, 193-195 (2003). DOI: $10.1021 / \mathrm{bm} 025728 \mathrm{~h}$

[40] Kurch N., Renard E., Brachet F., Robic D., Guerin P., Bourbouze R.: Poly(3-hydroxyoctanoate) containing pendant carboxylic groups for the preparation of nanoparticles aimed at drug transport and release. Polymer, 43, 1095-1101 (2002).

DOI: $10.1016 / \mathrm{S} 0032-3861(01) 00692-9$

[41] Eroğlu M. S., Hazer B., Ozturk T., Caykara T.: Hydroxylation of pendant vinyl groups of poly(3-hydroxy undec-10-enoate) in high yield. Journal of Applied Polymer Science, 97, 2132-2139 (2005). DOI: 10.1002/app.21943 
[42] Lee M. Y., Park W. H., Lenz R. W.: Hydrophilic bacterial polyesters modified with pendant hydroxyl groups. Polymer, 41, 1703-1709 (2000).

DOI: 10.1016/S0032-3861(99)00347-X

[43] Sparks J., Scholz C.: Synthesis and characterization of a cationic poly ( $\beta$-hydroxyalkanoate). Biomacromolecules, 9, 2091-2096 (2008).

DOI: $10.1021 / \mathrm{bm} 8005616$

[44] Bear M-M., Leboucher-Durand M-A., Langlois V., Lenz R. W., Goodwin S., Guerin P.: Bacterial poly-3hydroxyalkenoates with epoxy groups in the side chains. Reactive and Functional Polymers, 34, 65-77 (1997). DOI: $10.1016 / \mathrm{S} 1381-5148(97) 00024-2$

[45] Hazer D. B., Hazer B., Kaymaz F.: Synthesis of microbial elastomers based on soybean oily acids. Biocompatibility studies. Biomedical Materials, 4, 035011/1035011/9 (2009).

DOI: $10.1088 / 1748-6041 / 4 / 3 / 035011$

[46] Ilter S., Hazer B., Borcakli M., Atici O.: Graft copolymerisation of methyl methacrylate onto a bacterial polyester containing unsaturated side chains. Macromolecular Chemistry and Physics, 202, 2281-2286 (2001).

DOI: $10.1002 / 1521-3935(20010701) 202: 11<2281::$ AIDMACP2281>3.0.CO;2-9

[47] Toraman T., Hazer B.: Synthesis and characterization of the novel thermoresponsive conjugates based on poly (3-hydroxy alkanoates). Journal of Polymers and the Environment, 22, 159-166 (2014).

DOI: $10.1007 / \mathrm{s} 10924-014-0646-\mathrm{y}$

[48] Arkin A. H., Hazer B., Borcakli M.: Chlorination of poly (3-hydroxy alkanoates) containing unsaturated side chains. Macromolecules, 33, 3219-3223 (2000). DOI: $10.1021 / \mathrm{ma} 991535 \mathrm{j}$

[49] Li S., Cai L., Wu L., Zeng G., Chen J., Wu Q., Chen GQ.: Microbial synthesis of functional homo-, random, and block polyhydroxyalkanoates by $\beta$-oxidation deleted Pseudomonas entomophila. Biomacromolecules, 15, 2310-2319 (2014). DOI: $10.1021 / \mathrm{bm} 500669 \mathrm{~s}$

[50] Nguyen S., Yu G. E., Marchessault R. H.: Thermal degradation of poly(3-hydroxyalkanoates): Preparation of well-defined oligomers. Biomacromolecules, $\mathbf{3}$, 219-224 (2002).

DOI: $10.1021 / \mathrm{bm} 0156274$

[51] Kim J. K., Doi Y., Abe H.: Effects of residual metal compounds and chain-end structure on thermal degradation of poly(3-hydroxybutyric acid). Polymer Degradation and Stability, 91, 769-777 (2006).

DOI: $10.1016 /$ j.polymdegradstab.2005.06.004

[52] Lehrle R. S., Williams R. J.: Thermal degradation of bacterial poly(hydroxybutyric acid): Mechanisms from the dependence of pyrolysis yields on sample thickness. Macromolecules, 27, 3782-3789 (1994).

DOI: $10.1021 / \mathrm{ma} 00092 \mathrm{a} 017$
[53] Aoyagi Y., Yamashita K., Doi Y.: Thermal degradation of poly[( $R)$-3-hydroxybutyrate], poly[ $\varepsilon$-caprolactone], and poly $[(S)$-lactide]. Polymer Degradation and Stability, 76, 53-59 (2002).

DOI: 10.1016/S0141-3910(01)00265-8

[54] Kawalec M., Sobota M., Scandola M., Kowalczuk M., Kurcok P.: A convenient route to PHB macromonomers via anionically controlled moderate-temperature degradation of PHB. Journal of Polymer Science Part A: Polymer Chemistry, 48, 5490-5497 (2010). DOI: $10.1002 /$ pola. 24357

[55] Liu Q-S., Zhu M-F., Wu W-H., Qin Z-Y.: Reducing the formation of six-membered ring ester during thermal degradation of biodegradable PHBV to enhance its thermal stability. Polymer Degradation and Stability, 94, 18-24 (2009).

DOI: $10.1016 /$ j.polymdegradstab.2008.10.016

[56] Hirt T. D., Neuenschwander P., Suter U. W.: Telechelic diols from poly $[(R)-3$-hydroxybutyric acid] and poly $\{[(R)$-3-hydroxybutyric acid $]$-co-[(R)-3-hydroxyvaleric acid]\}. Macromolecular Chemistry and Physics, 197, 1609-1614 (1996).

DOI: $10.1002 /$ macp. 1996.021970503

[57] Ballistreri A., Garozzo D., Giuffrida M., Impallomeni G., Montaudo G.: Sequencing bacterial poly $(\beta-$ hydroxybutyrate-co- $\beta$-hydroxyvalerate) by partial methanolysis, HPLC fractionation, and fast-atom-bombardment mass spectrometry analysis. Macromolecules, 22, 2107-2111 (1989).

DOI: $10.1021 / \mathrm{ma} 00195 \mathrm{a} 016$

[58] Reeve M. S., McCarthy S. P., Gross R. A.: Preparation and characterization of $(R)$-poly( $\beta$-hydroxybutyrate)poly( $\varepsilon$-caprolactone) and $(R)$-poly( $\beta$-hydroxybutyrate)poly(lactide) degradable diblock copolymers. Macromolecules, 26, 888-894 (1993).

DOI: $10.1021 / \mathrm{ma} 00057 \mathrm{a} 002$

[59] Špitalský Z., Lacík I., Lathová E., Janigová I., Chodák I.: Controlled degradation of polyhydroxybutyrate via alcoholysis with ethylene glycol or glycerol. Polymer Degradation and Stability, 91, 856-861 (2006). DOI: 10.1016/j.polymdegradstab.2005.06.019

[60] Akita S., Einaga Y., Miyaki Y., Fujita H.: Solution properties of poly(D- $\beta$-hydroxybutyrate). 1. Biosynthesis and characterization. Macromolecules, 9, 774-780 (1976).

DOI: $10.1021 / \mathrm{ma} 60053 \mathrm{a} 017$

[61] Freier T., Kunze C., Nischan C., Kramer S., Sternberg K., Saß M., Hopt U. T., Schmitz K. P.: In vitro and in vivo degradation studies for development of a biodegradable patch based on poly(3-hydroxybutyrate). Biomaterials, 23, 2649-2657 (2002).

DOI: 10.1016/S0142-9612(01)00405-7

[62] Ke Y., Qu Z., Wu G., Wang Y.: Thermal and in vitro degradation properties of the $\mathrm{NH}_{2}$-containing PHBV films. Polymer Degradation and Stability, 105, 59-67 (2014).

DOI: 10.1016/j.polymdegradstab.2014.03.039 
[63] Yu J., Plackett D., Chen L. X. L.: Kinetics and mechanism of the monomeric products from abiotic hydrolysis of poly $[(R)$-3-hydroxybutyrate $]$ under acidic and alkaline conditions. Polymer Degradation and Stability, 89, 289-299 (2005).

DOI: 10.1016/j.polymdegradstab.2004.12.026

[64] Yu G-E., Marchessault R. H.: Characterization of low molecular weight poly( $\beta$-hydroxybutyrate)s from alkaline and acid hydrolysis. Polymer, 41, 1087-1098 (2000). DOI: 10.1016/S0032-3861(99)00230-X

[65] Deng X. M., Hao J. Y.: Synthesis and characterization of poly(3-hydroxybutyrate) macromer of bacterial origin. European Polymer Journal, 37, 211-214 (2001). DOI: 10.1016/S0014-3057(00)00090-2

[66] Michalak M., Marek A. A., Zawadiak J., Kawalec M., Kurcok P.: Synthesis of PHB-based carrier for drug delivery systems with $\mathrm{pH}$-controlled release. European Polymer Journal, 49, 4149-4156 (2013).

DOI: 10.1016/j.eurpolymj.2013.09.021

[67] Arkin A. H., Hazer B.: Chemical modification of chlorinated microbial polyesters. Biomacromolecules, 3, 1327-1335 (2002).

DOI: $10.1021 / \mathrm{bm} 020079 \mathrm{~V}$

[68] Yalpani M., Marchessault R. H., Morin F. G., Monasterios C. J.: Synthesis of poly(3-hydroxyalkanoate) (PHA) conjugates: PHA-carbohydrate and PHA-synthetic polymer conjugates. Macromolecules, 24, 60466049 (1991).

DOI: $10.1021 / \mathrm{ma} 00022 \mathrm{a} 024$

[69] Yu G., Morin F. G., Nobes G. A. R., Marchessault R. H.: Degree of acetylation of chitin and extent of grafting PHB on chitosan determined by solid state ${ }^{15} \mathrm{~N}$ NMR. Macromolecules, 32, 518-520 (1999).

DOI: $10.1021 / \mathrm{ma9} 913338$

[70] Andrade A. P., Witholt B., Chang D. L., Li Z.: Synthesis and characterization of novel thermoplastic polyester containing blocks of poly[ $(R)$-3-hydroxyoctanoate $]$ and poly $[(R)-3$-hydroxybutyrate]. Macromolecules, 36, 9830-9835 (2003). DOI: $10.1021 / \mathrm{ma} 035164 \mathrm{p}$

[71] Li J., Li X., Ni X., Leong K. W.: Synthesis and characterization of new biodegradable amphiphilic poly(ethylene oxide)- $b$-poly[( $R)$-3-hydroxy butyrate]- $b$-poly(ethylene oxide) triblock copolymers. Macromolecules, 36, 2661-2667 (2003).

DOI: $10.1021 / \mathrm{ma} 025725 \mathrm{x}$

[72] Li X., Mya K. Y., Ni X. P., He C. B., Leong K. W., Li J.: Dynamic and static light scattering studies on selfaggregation behavior of biodegradable amphiphilic poly(ethylene oxide)-poly[( $R)$-3-hydroxybutyrate $]-$ poly(ethylene oxide) triblock copolymers in aqueous solution. Journal of Physical Chemistry B, 110, 5920 5926 (2006).

DOI: $10.1021 / \mathrm{jp} 057004 \mathrm{~g}$
[73] Wu L. P., Wang L., Wang X. J., Xu K. T.: Synthesis, characterizations and biocompatibility of novel biodegradable star block copolymers based on poly $[(R)$ 3 -hydroxybutyrate] and poly( $\varepsilon$-caprolactone). Acta Biomaterialia, 6, 1079-1089 (2010). DOI: 10.1016/j.actbio.2009.08.014

[74] Nguyen S., Marchessault R. H.: Synthesis and properties of graft copolymers based on poly(3-hydroxybutyrate) macromonomers. Macromolecular Bioscience, 4, 262-268 (2004). DOI: $10.1002 / \mathrm{mabi} .200300088$

[75] Chen Z., Cheng S., Li Z., Xu K., Chen G.: Synthesis, characterization and cell compatibility of novel poly (ester urethane)s based on poly(3-hydroxybutyrate-co4-hydroxybutyrate) and poly(3-hydroxybutyrate-co-3hydroxyhexanoate) prepared by melting polymerization. Journal of Biomaterials Science, Polymer Edition, 20, 1451-1471 (2009).

DOI: $10.1163 / 092050609 X 12457419007621$

[76] Chen Z., Cheng S., Xu K.: Block poly(ester-urethane)s based on poly(3-hydroxybutyrate-co-4-hydroxybutyrate) and poly(3-hydroxyhexanoate-co-3-hydroxyoctanoate). Biomaterials, 30, 2219-2230 (2009). DOI: 10.1016/j.biomaterials.2008.12.078

[77] Ou W., Qiu H., Chen Z., Xu K.: Biodegradable block poly(ester-urethane)s based on poly(3-hydroxybutyrate-co-4-hydroxybutyrate) copolymers. Biomaterials, 32, 3178-3188 (2011).

DOI: 10.1016/j.biomaterials.2011.01.031

[78] Saad G. R., Lee Y. J., Seliger H.: Synthesis and characterization of biodegradable poly(ester-urethanes) based on bacterial poly(R-3-hydroxybutyrate). Journal of Applied Polymer Science, 83, 703-718 (2002). DOI: $10.1002 / a p p .2265$

[79] Saad G. R., Seliger H.: Biodegradable copolymers based on bacterial poly((R)-3-hydroxybutyrate): Thermal and mechanical properties and biodegradation behaviour. Polymer Degradation and Stability, 83, 101110 (2004). DOI: 10.1016/S0141-3910(03)00230-1

[80] Häberlein H., Seliger H., Kohler R., Sulzberger P.: Cost-effective synthesis of environmentally benign materials on the basis of poly-3-hydroxybutyrate. Polímeros, 15, 122-126 (2005). DOI: $10.1590 / \mathrm{S} 0104-14282005000200011$

[81] Seliger H., Häberlein H.: Biodegradable composite system and the use thereof. U.S. Patent 8835573, USA (2014).

[82] Zhao Q., Cheng G.: Preparation of biodegradable poly (3-hydroxybutyrate) and poly(ethylene glycol) multiblock copolymers. Journal of Materials Science, 39, 3829-3831 (2004).

DOI: 10.1023/B:JMSC.0000030750.87512.07 
[83] Li Z., Cheng S., Li S., Liu Q., Xu K., Chen G.: Novel amphiphilic poly(ester-urethane)s based on poly[ $[(R)-3$ hydroxyalkanoate]: Synthesis, biocompatibility and aggregation in aqueous solution. Polymer International, 57, 887-894 (2008).

DOI: $10.1002 /$ pi.2424

[84] Li Z., Yang X., Wu L., Chen Z., Lin Y., Xu K., Chen G.: Synthesis, characterization and biocompatibility of biodegradable elastomeric poly(ether-ester urethane)s based on poly(3-hydroxybutyrate-co-3-hydroxyhexanoate) and poly(ethylene glycol) via melting polymerization. Journal of Biomaterials Science, Polymer Edition, 20, 1179-1202 (2009).

DOI: $10.1163 / 156856209 X 452944$

[85] Zhao Q., Cheng G., Li H., Ma X., Zhang L.: Synthesis and characterization of biodegradable poly(3-hydroxybutyrate) and poly(ethylene glycol) multiblock copolymers. Polymer, 46, 10561-10567 (2005).

DOI: $10.1016 /$ j.polymer.2005.08.014

[86] Li X., Loh X. J., Wang K., He C. B., Li J.: Poly(ester urethane)s consisting of poly[(R)-3-hydroxybutyrate] and poly(ethylene glycol) as candidate biomaterials: Characterization and mechanical property study. Biomacromolecules, 6, 2740-2747 (2005).

DOI: $10.1021 / \mathrm{bm} 050234 \mathrm{~g}$

[87] Liu K. L., Choo E. S. G., Wong S. Y., Li X., He C. B., Wang J., Li J.: Designing poly[(R)-3-hydroxybutyrate]based polyurethane block copolymers for electrospun nanofiber scaffolds with improved mechanical properties and enhanced mineralization capability. Journal of Physical Chemistry B, 114, 7489-7498 (2010).

DOI: $10.1021 / j p 1018247$

[88] Naguib H. F., Aziz M. S. A., Sherif S. M., Saad G. R.: Synthesis and thermal characterization of poly(esterether urethane)s based on PHB and PCL-PEG-PCL blocks. Journal of Polymer Research, 18, 1217-1227 (2011).

DOI: $10.1007 / \mathrm{s} 10965-010-9525-\mathrm{y}$

[89] Saad G. R.: Calorimetric and dielectric study of the segmented biodegradable poly(ester-urethane)s based on bacterial poly[(R)-3-hydroxybutyrate]. Macromolecular Bioscience, 1, 387-396 (2001).

DOI: 10.1002/1616-5195(20011201)1:9<387::AID-

$$
\text { MABI387>3.0.CO;2-4 }
$$

[90] Saad B., Ciardelli G., Matter S., Welti M., Uhlschmid G. K., Neuenschwander P., Suter U. W.: Characterization of the cell response of cultured macrophages and fibroblasts to particles of short-chain poly[(R)-3-hydroxybutyric acid]. Journal of Biomedical Materials Research, 30, 429-439 (1996).

DOI: 10.1002/(SICI) 1097-4636(199604)30:4<429:: AID-JBM1>3.0.CO;2-R
[91] Saad B., Ciardelli G., Matter S., Welti M., Uhlschmid G. K., Neuenschwander P., Suter U. W.: Degradable and highly porous polyesterurethane foam as biomaterial: Effects and phagocytosis of degradation products in osteoblasts. Journal of Biomedical Materials Research, 39, 594-602 (1998).

DOI: 10.1002/(SICI)1097-4636(19980315)39:4<594 $\because$ AID-JBM14>3.0.CO;2-7

[92] Loh X. J., Goh S. H., Li J.: New biodegradable thermogelling copolymers having very low gelation concentrations. Biomacromolecules, 8, 585-593 (2007). DOI: $10.1021 / \mathrm{bm} 0607933$

[93] Loh X. J., Goh S. H., Li J.: Biodegradable thermogelling poly[ $[R)$-3-hydroxybutyrate]-based block copolymers: Micellization, gelation, and cytotoxicity and cell culture studies. Journal of Physical Chemistry B, 113, 11822-11830 (2009). DOI: $10.1021 / j p 903984 \mathrm{r}$

[94] Liu Q., Cheng S., Li Z., Xu K., Chen G-Q.: Characterization, biodegradability and blood compatibility of poly[(R)-3-hydroxybutyrate] based poly(ester-urethane)s. Journal of Biomedical Materials Research Part A, 90, 1162-1176 (2009).

DOI: $10.1002 / \mathrm{jbm} . \mathrm{a} .32180$

[95] Lendlein A., Neuenschwander P., Suter U. W.: Tissuecompatible multiblock copolymers for medical applications, controllable in degradation rate and mechanical properties. Macromolecular Chemistry and Physics, 199, 2785-2796 (1998).

DOI: 10.1002/(SICI)1521-3935(19981201)199:12< 2785::AID-MACP2785>3.0.CO;2-X

[96] Hirt T. D., Neuenschwander P., Suter U. W.: Synthesis of degradable, biocompatible, and tough block-copolyesterurethanes. Macromolecular Chemistry and Physics, 197, 4253-4268 (1996).

DOI: $10.1002 /$ macp.1996.021971221

[97] Saad B., Neuenschwander P., Uhlschmid G. K., Suter U. W.: New versatile, elastomeric, degradable polymeric materials for medicine. International Journal of Biological Macromolecules, 25, 293-301 (1999). DOI: 10.1016/S0141-8130(99)00044-6

[98] Andrade A. P., Neuenschwander P., Hany R., Egli T., Witholt B., Li Z.: Synthesis and characterization of novel copoly(ester-urethane) containing blocks of poly$[(R)$-3-hydroxyoctanoate $]$ and poly- $[(R)$-3-hydroxybutyrate]. Macromolecules, 35, 4946-4950 (2002). DOI: $10.1021 / \mathrm{ma} 012223 \mathrm{v}$

[99] Pan J., Li G., Chen Z., Chen X., Zhu W., Xu K.: Alternative block polyurethanes based on poly(3-hydroxybutyrate-co-4-hydroxybutyrate) and poly(ethylene glycol). Biomaterials, 30, 2975-2984 (2009). DOI: $10.1016 /$ j.biomaterials.2009.02.005

[100] Arslan H., Menteş A., Hazer B.: Synthesis and characterization of diblock, triblock, and multiblock copolymers containing poly(3-hydroxy butyrate) units. Journal of Applied Polymer Science, 94, 1789-1796 (2004). DOI: 10.1002/app.21112 
[101] Nuyken O., Pask S. D.: Ring-opening polymerization - An introductory review. Polymers, 5, 361-403 (2013). DOI: $10.3390 /$ polym5020361

[102] Isono T., Asai S., Satoh Y., Takaoka T., Tajima K., Kakuchi T., Satoh T.: Controlled/living ring-opening polymerization of glycidylamine derivatives using $t$ $\mathrm{Bu}-\mathrm{P}_{4} /$ alcohol initiating system leading to polyethers with pendant primary, secondary, and tertiary amino groups. Macromolecules, 48, 3217-3229 (2015).

DOI: 10.1021 acs.macromol.5b00556

[103] Kwiecień I., Adamus G., Bartkowiak A., Kowalczuk M.: Synthesis and structural characterization at the molecular level of oligo(3-hydroxybutyrate) conjugates with antimicrobial agents designed for food packaging materials. Designed Monomers and Polymers, 17, 311-321 (2014).

DOI: $10.1080 / 15685551.2013 .840505$

[104] Maksymiak M., Kowalczuk M., Adamus G.: Electrospray tandem mass spectrometry for the structural characterization of p-coumaric acid-oligo(3-hydroxybutyrate) conjugates. International Journal of Mass Spectrometry, 359, 6-11 (2014). DOI: $10.1016 /$ j.ijms.2013.11.009

[105] Adamus G., Sikorska W., Janeczek H., Kwiecień M., Sobota M., Kowalczuk M.: Novel block copolymers of atactic PHB with natural PHA for cardiovascular engineering: Synthesis and characterization. European Polymer Journal, 48, 621-631 (2012). DOI: 10.1016/j.eurpolymj.2011.12.017

[106] Adamus G., Sikorska W., Kowalczuk M., Montaudo M., Scandola M.: Sequence distribution and fragmentation studies of bacterial copolyester macromolecules: Characterization of PHBV macroinitiator by electrospray ion-trap multistage mass spectrometry. Macromolecules, 33, 5797-5802 (2000).

DOI: $10.1021 / \mathrm{ma} 000005 \mathrm{~g}$

[107] Iwata T., Doi Y., Kasuya K-I., Inoue Y.: Visualization of enzymatic degradation of poly[ $(R)$-3-hydroxybutyrate] single crystals by an extracellular PHB depolymerase. Macromolecules, 30, 833-839 (1997). DOI: $10.1021 / \mathrm{ma} 961352 \mathrm{~m}$

[108] Liu Q., Deng B., Tung C-H., Zhu M., Shyr T-W.: Nonisothermal crystallization kinetics of poly( $\varepsilon$-caprolactone) blocks in double crystalline triblock copolymers containing poly(3-hydroxybutyrate-co-3-hydroxyvalerate) and poly( $\varepsilon$-caprolactone) units. Journal of Polymer Science Part B: Polymer Physics, 48, 2288-2295 (2010).

DOI: $10.1002 /$ polb.22112

[109] Wu L., Chen S., Li Z., Xu K., Chen G-Q.: Synthesis, characterization and biocompatibility of novel biodegradable poly $[((R)-3$-hydroxybutyrate)-block-(D,Llactide)-block-(E-caprolactone)] triblock copolymers. Polymer International, 57, 939-949 (2008).

DOI: $10.1002 /$ pi.2431
[110] Ayres N.: Atom transfer radical polymerization: A robust and versatile route for polymer synthesis. Polymer Reviews, 51, 138-162 (2011). DOI: $10.1080 / 15583724.2011 .566402$

[111] Xue C-H., Guo X-J., Ma J-Z., Jia S-T.: Fabrication of robust and antifouling superhydrophobic surfaces via surface-initiated atom transfer radical polymerization. ACS Applied Materials and Interfaces, 7, 8251-8259 (2015).

DOI: $10.1021 /$ acsami.5b01426

[112] Loh X. J., Zhang Z-X., Wu Y-L., Lee T. S., Li J.: Synthesis of novel biodegradable thermoresponsive triblock copolymers based on poly[(R)-3-hydroxybutyrate] and poly $(N$-isopropylacrylamide $)$ and their formation of thermoresponsive micelles. Macromolecules, 42, 194-202 (2009).

DOI: $10.1021 / \mathrm{ma} 8019865$

[113] Loh X. J., Ong S. J., Tung Y. T., Choo H. T.: Incorporation of poly $[(R)$-3-hydroxybutyrate] into cationic copolymers based on poly(2-(dimethylamino)ethyl methacrylate) to improve gene delivery. Macromolecular Bioscience, 13, 1092-1099 (2013).

DOI: $10.1002 / \mathrm{mabi} .201300050$

[114] Zhang X., Yang H., Liu Q., Zheng Y., Xie H., Wang Z., Cheng R.: Synthesis and characterization of biodegradable triblock copolymers based on bacterial poly $[(R)-$ 3-hydroxybutyrate] by atom transfer radical polymerization. Journal of Polymer Science Part A: Polymer Chemistry, 43, 4857-4869 (2005).

DOI: $10.1002 /$ pola.20953

[115] Neugebauer D., Rydz J., Goebel I., Dacko P., Kowalczuk M.: Synthesis of graft copolymers containing biodegradable poly(3-hydroxybutyrate) chains. Macromolecules, 40, 1767-1773 (2007).

DOI: $10.1021 / \mathrm{ma} 062251 \mathrm{j}$

[116] Arslan H., Yesilyurt N., Hazer B.: Brush type copolymers of poly(3-hydroxybutyrate) and poly(3-hydroxyoctanoate) with same vinyl monomers via 'grafting from' technique by using atom transfer radical polymerization method. Macromolecular Symposia, 269, 23-33 (2008). DOI: $10.1002 /$ masy.200850905

[117] Arslan H., Yeşilyurt N., Hazer B.: The synthesis of poly(3-hydroxybutyrate)- $g$-poly(methylmethacrylate) brush type graft copolymers by atom transfer radical polymerization method. Journal of Applied Polymer Science, 106, 1742-1750 (2007).

DOI: $10.1002 / a p p .26870$

[118] Koseva N. S., Novakov C. P., Rydz J., Kurcok P., Kowalczuk M.: Synthesis of aPHB-PEG brush copolymers through ATRP in a macroinitiator-macromonomer feed system and their characterization synthesis of aPHB-PEG brush co-polymers through ATRP in a macroinitiator-macromonomer feed system and their characterization. Designed Monomers and Polymers, 13, 579-595 (2010). DOI: $10.1163 / 138577210 \times 530675$ 
[119] Nguyen S., Marchessault R. H.: Atom transfer radical copolymerization of bacterial poly(3-hydroxybutyrate) macromonomers and methyl methacrylate. Macromolecules, 38, 290-296 (2005).

DOI: $10.1021 / \mathrm{ma} 048899 \mathrm{i}$

[120] Cai Z. J., Yang G.: Copolymerization of poly(hydroxybutyrate) and poly(ethylene glycol) by coupling method (in Chinese). Polymer Materials Science and Engineering, 27, 145-148 (2011).

[121] Hazer B.: Preparation of polystyrene poly $(\beta$-hydroxy nonanoate) graft copolymers. Polymer Bulletin, 33, 431-438 (1994).

DOI: $10.1007 / \mathrm{BF} 00293487$

[122] Hazer B.: Poly( $\beta$-hydroxynonanoate) and polystyrene or poly(methyl methacrylate) graft copolymers: Microstructure characteristics and mechanical and thermal behavior. Macromolecular Chemistry and Physics, 197, 431-441 (1996).

DOI: 10.1002/macp.1996.021970202

[123] Erbil H. Y., Hazer B.: Surface free energy analysis of polystyrene-poly( $\beta$-hydroxynonanoate) graft copolymers. Journal of Applied Polymer Science, 60, 13131320 (1996).

DOI: 10.1002/(SICI)1097-4628(19960531)60:9<1313 $\because$ AID-APP6>3.0.CO;2-M

[124] Kwiecień I., Radecka I., Kowalczuk M., Adamus G.: Transesterification of PHA to oligomers covalently bonded with (bio)active compounds containing either carboxyl or hydroxyl functionalities. PloS one, 10, e0120149/1-e0120149/20 (2015).

DOI: $10.1371 /$ journal.pone.0120149

[125] Ravenelle F., Marchessault R. H.: One-step synthesis of amphiphilic diblock copolymers from bacterial poly([R]-3-hydroxybutyric acid). Biomacromolecules, 3, 1057-1064 (2002).

DOI: $10.1021 / \mathrm{bm} 025553 \mathrm{~b}$

[126] Chen C., Fei B., Peng S. W., Zhuang Y. G., Chen X. S., Dong L. S., Feng Z. L.: Study on the transesterification of poly( $\beta$-hydroxybutyrate) and poly( $\varepsilon$-caprolactone) (in Chinese). Acta Polymerica Sinica, 2, 142 148 (2002).

[127] Park J., Park J-G., Choi W-M., Ha C-S., Cho W-J.: Synthesis and photo- and biodegradabilities of poly [(hydroxybutyrate-co-hydroxyvalerate)- $g$-phenyl vinyl ketone]. Journal of Applied Polymer Science, 74, 1432-1439 (1999).

DOI: $10.1002 /($ SICI)1097-4628(19991107)74:6<1432 $\because$ AID-APP16>3.0.CO;2-Z

[128] Chen C., Peng S., Fei B., An Y., Zhuang Y., Dong L., Feng Z., Chen S., Xia H.: Study on the properties of poly( $\beta$-hydroxybutyrate) grafted with maleic anhydride (in Chinese). Acta Polymerica Sinica, 4, 450 454 (2001).
[129] Chen C., Peng S. W., Fei B., Zhuang Y. G., Dong L. S., Feng Z. L., Chen S., Xia H. M.: Synthesis and characterization of maleated poly(3-hydroxybutyrate). Journal of Applied Polymer Science, 88, 659-668 (2003).

DOI: 10.1002/app.11771

[130] Chen C., Fei B., Peng S. W., Zhuang Y. G., Dong L. S., Feng Z. L.: Isothermal crystallization kinetics and melting behavior of poly( $\beta$-hydroxybutyrate) and maleated poly( $\beta$-hydroxybutyrate) (in Chinese). Acta Polymerica Sinica, 1, 68-72 (2002).

[131] Chen C., Peng S. W., Fei B., An Y. X., Zhuang Y. G., Dong L. S., Feng Z. L.: Study on the free radical graft copolymerization of maleic anhydride onto $\operatorname{poly}(\beta-$ hydroxybutyrate) (in Chinese). Chinese Journal of Applied Chemistry, 1, 12-15 (2001).

[132] Mitomo H., Enjôji T., Watanabe Y., Yoshii F., Makuuchi K., Saito T.: Radiation-induced graft polymerization of poly(3-hydroxybutyrate) and its copolymer. Journal of Macromolecular Science Part A: Pure and Applied Chemistry, 32, 429-442 (1995). DOI: $10.1080 / 10601329508013674$

[133] Mitomo H., Watanabe Y., Yoshii F., Makuuchi K.: Radiation effect on polyesters. Radiation Physics and Chemistry, 46, 233-238 (1995).

DOI: 10.1016/0969-806X(95)00018-S

[134] Bahari K., Mitomo H., Enjôji T., Hasegawa S., Yoshii F., Makuuchi K.: Radiation-induced graft polymerization of styrene onto poly(3-hydroxybutyrate) and its copolymer with 3-hydroxyvalerate. Die Angewandte Makromolekulare Chemie, 250, 31-44 (1997).

DOI: 10.1002/apmc.1997.052500103

[135] Bahari K., Mitomo H., Enjôji T., Yoshii F., Makuuchi K.: Degradability of poly(3-hydroxybutyrate) and its copolymer grafted with styrene by radiation. Polymer Degradation and Stability, 61, 245-252 (1998).

DOI: 10.1016/S0141-3910(97)00147-X

[136] Jiang T., Hu P.: Radiation-induced graft polymerization of isoprene onto polyhydroxybutyrate. Polymer Journal, 33, 647-653 (2001). DOI: $10.1295 /$ polymj.33.647

[137] Mitomo H., Sasaoka T., Yoshii F., Makuuchi K., Saito T.: Radiation-induced graft polymerization of acrylic acid onto poly (3-hydroxybutyrate) and its copolymer. Sen'i Gakkaishi, 52, 623-626 (1996). DOI: $10.2115 /$ fiber.52.11 623

[138] Ye H., Yang D., Hu P., Zhang F., Qi Q., Zhao W.: Grafting of maleic anhydride onto poly( $\beta$-hydroxybutyrate) by ${ }^{60} \mathrm{Co} \gamma$ radiation. Acta Polymerica Sinica, 5, 678-682 (2005).

[139] Hazer B., Lenz R. W., Çakmakli B., Borcakli M., Koçer H.: Preparation of poly(ethylene glycol) grafted poly(3hydroxyalkanoate) networks. Macromolecular Chemistry and Physics, 200, 1903-1907 (1999).

DOI: 10.1002/(SICI)1521-3935(19990801)200:8<1903 ::AID-MACP1903>3.0.CO;2-J 